\title{
Applicability of the Korean Development Model for Africa
}

\section{Lessons of Fundamentals of Economics and Industrialization}

Sub-Saharan African countries are still grappling with the issue of how to tackle poverty and move up the economic ladder. For any poor country wanting to break out of its lot and join the ranks of rich nations, realizing structural, wide-ranging and continuous changes in all sectors is a necessity. Those economies that have successfully emerged in a transformative fashion were able to do so because they were progressing on multiple fronts, as was the case in many East Asian and Southeast Asian nations. South Korea pushed forward many social, educational, economic and governmental 'reforms' and launched industrialization and rural development in a 'concurrent' manner.

The worst-case scenario would be where a poor country with no resources remains idle and fails to undertake any significant economic initiatives. Resource-rich countries are better off as they can rely on these resources, but the danger of the Dutch Disease (the problem of production of natural resources causing a decline in other sectors like manufacturing) wrought by a commodity-based monocultural economy 
looms in these countries. Hence, an unsavoury recipe for the countries would be a combination of a resource-rich, commodity-dependent structure with bad management, and a lack of sense of ownership or a workable strategy. Evidently, hardly any countries have successfully developed simply by relying on their natural resources.

An IMF report released in April, 2017 confirmed that oil-exporting countries and other resource-intensive countries in Sub-Saharan Africa were showing the worst economic performance in the region. ${ }^{1}$ Even countries like Botswana and Zambia that enjoyed a reputation for good governance and were regarded as models in Sub-Saharan Africa experienced problems related to a commodity-dependent economy. Traditionally, African economies which are primarily reliant on agricultural produce like cacao, coffee and tea have experienced vulnerability with the fluctuation of international market prices. While commodity prices have been recovering in 2018, various economic forecasts point to rather sluggish growth for the resource-rich African countries.

And then, of course, we see a preponderance of economic liberalization, free trade and investment in Africa. Somehow, the myth that privatization, liberalization and the influx of foreign companies will, in themselves, unleash the full economic potential of their country has settled in Africa. In appearance, this has all the bearings of a positive trend and can certainly help, but it masks the untoward side of the reality. In order or any policy to be successful, the government must assume responsibility and a hands-on posture. All policies have drawbacks as well as advantages, and this should not be forgotten. Furthermore, different policies require different conditions and although trial and error is inevitable, appropriate rectifying measures must follow. However, the tendency seems to be that the authorities opt for convenience and the easy way out.

Basically, in order for any organization to function properly, it would require positive leadership from the top and adherence to its rules or policies by the members. The stronger such traits are, the more efficient the organization will be. And in the case of governmental bureaucracy, this should be all the more evident. The bigger the hierarchical structure of an organization, the greater the 'trickle-down effect' the quality of leadership 
will have on the organization. There is an old Korean saying that 'upper stream water must be clean for downstream water to be clean'.

There is also a cliché that says 'action speaks louder than words'. Public services are delivered by actions, and the timely provision of services is of the utmost importance. The credibility, authority and efficiency of the state stem from the everyday performance of the governmental bureaucracy, which is determined by the devotion and actions of civil servants. When we are talking about producing real outcomes, that is, being productive, we mean making an improvement over time. The variables are intrinsically 'change' and 'speed', or how fast this change can be made. Change or improvement can be either quantitative or qualitative, or both. The measure of progress is how much and how fast things can be done.

Myopic vision, which is not looking ahead, and expediency, which is choosing what is convenient now rather than what will yield better results tomorrow, both come with costs. A typical example is when requests are made to build factories, training institutes, etc., but after they have gotten them from development partners, the familiar pattern of mismanagement ensues. Often the training and consulting provided to local officials and operators are rendered futile as soon as they are handed over. Of course, some projects manage to survive and last as intended, proving to be useful, but these are the exceptions to the rule.

Also, in many countries, there seems to be a tendency for people wanting things for the sake of 'possession', as an end in themselves, rather than to utilize them as a means to extract additional or greater benefits. I have met many African officials, businessmen and rural leaders who would say that once they receive investments and factories, everything else will take care of itself. But in order to run a factory, people need utilities, management, maintenance, skills and capacities, funding, etc. Securing a facility in its physical form is one thing, but operating it successfully is another thing entirely.

In the context of addressing poverty, African leaders are urging their rural populace to get out of the subsistence way of life and engage in more productive activities to generate income. For peasants, subsistence means getting by with what they can find around them without being far-sighted 
and having a long-term plan in place. However, the problem of 'subsistence' is also inherent in other sectors, including the public sector.

As laid out in the African Union (AU)'s Agenda 2063, all African countries aspire to growth and sustainable development, and aim for a 'structurally transformed' economy. And every leader seems to have industrialization in mind. It will be difficult to imagine having structural transformation of economy without industrialization or a manufacturing sector. Figure 9.1 represents manufacturing as a percentage of GDP, comparing Sub-Saharan Africa with East Asia, Southeast Asia, and Latin America and the Caribbean. It shows the persistently low level of Africa's manufacturing sector in its post-independence era. Interestingly, in the early 1960s, Sub-Saharan Africa started with a higher percentage compared to East Asia, but now there is about a $15 \%$ difference between them: the figure for East Asia is about 25\%, while Sub-Saharan Africa is hovering around 10\%, and this is even lower than Southeast Asia, and Latin America and the Caribbean.

The challenge, as well as the opportunity, facing Africa's manufacturing is shown in the composition of import and exports in Fig. 9.2. Manufactured goods make up almost $60 \%$ of its imports, while energy (mostly oil) constitutes the dominant export. Agriculture makes up

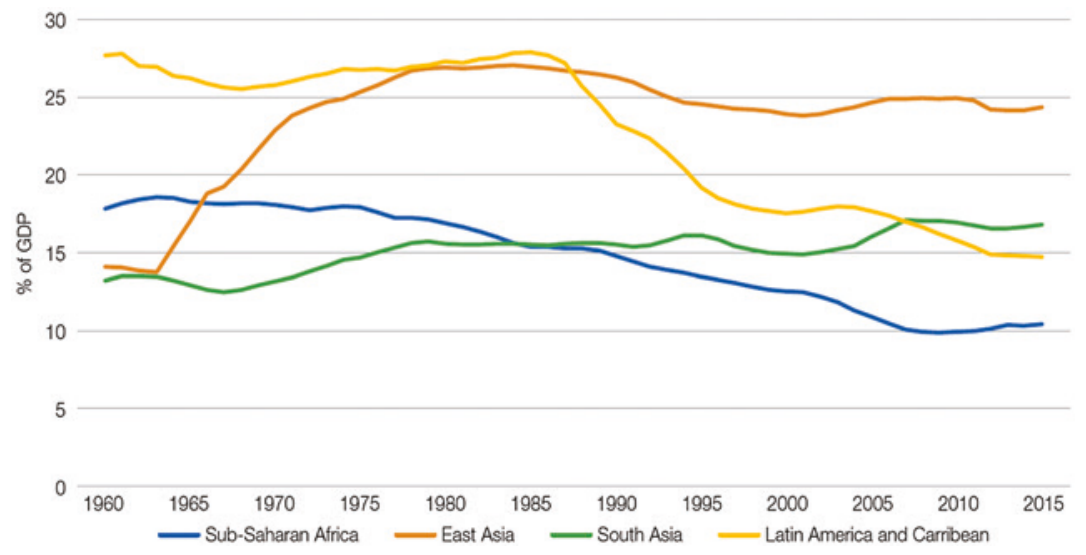

Fig. 9.1 Manufacturing as a percentage of GDP by selected global regions (Source calculation in Ifs v. 7.33 (five-year average); ISS South Africa, 'Made in Africa' (April 2018)) 


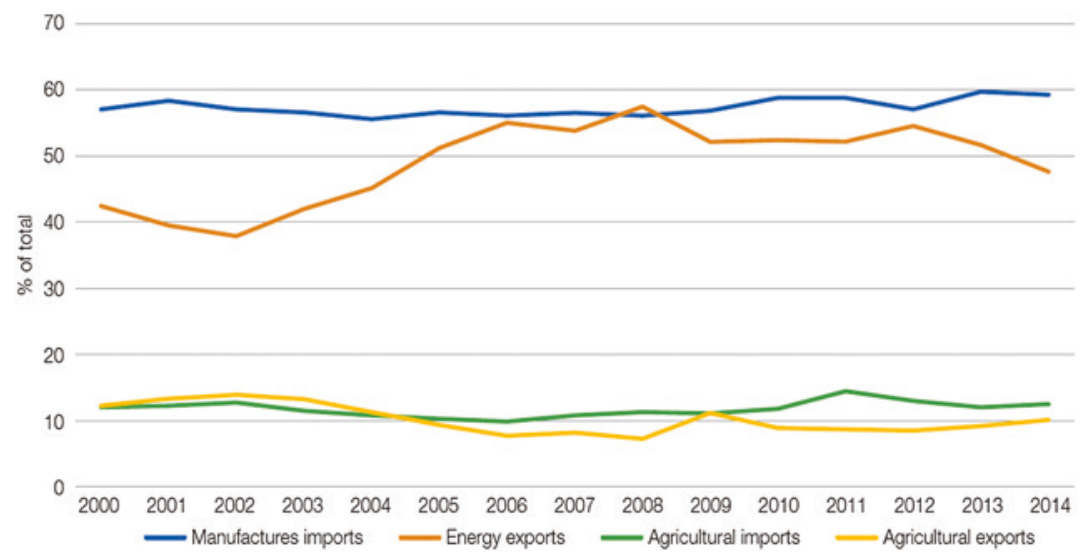

Fig. 9.2 Most important import and export sectors: Africa's trade with world (rest) (Source calculation in IFS? v. 7.33; ISS South Africa, 'Made in Africa' (April 2018))

around $12 \%$ of imports and around $10 \%$ of exports. Sub-Saharan Africa has a huge agricultural potential, but its dependence on food imports is growing, with nine countries depending on imports for more than $40 \%$ of their demand. ${ }^{2}$ The weakness in African countries' manufacturing is closely related to the uncompetitiveness or high cost of its labour force relative to their average income levels, which is the combination of many things: workers' skill levels, poor infrastructure, institutions, health conditions, etc. Hence, it is generally considered that 'African labour cost needs to be cheap enough to compensate for other benefits. South Africa stands out as a middle-income country with particularly high labour costs and a very capital-intensive industrial sector'. ${ }^{3}$

Exports are what African countries have counted on, but their share of global exports has declined over the past 35 years from $4.5 \%$ in 1980 to $3.0 \%$ in 2015 , and the exported items are mainly commodities, with the share of manufacturing exports declining from 0.4 to $0.3 \%$ over the same period. ${ }^{4}$ Even maintaining their level of exports, let alone expanding and upgrading industrial capacity, is not a simple task. In 2016, Africa's GDP growth fell to $1.4 \%$, its slowest rate for more than two decades. $^{5}$ 
There is a choice that Sub-Saharan African countries have to make: first, they can either accept the hard reality and make the most of (or do what best they could with) the given economic conditions; or, alternatively, they can make extraordinary efforts to transform and upgrade their industrial and economic structure adopting a set of different and bold measures. But neither of these two options would be comfortable ones for African countries to espouse. The first choice would be difficult for countries to bear because what it really means is resigning to the reality and the status quo, while the second choice entails significant burdens, commitment, endurance, focus and effective mobilization of work.

The choice is up to each Sub-Saharan African nation to make, but most African countries can end up stuck in the middle between these two options. What Africa leaders and elites really have in mind, and what they intend to do, matters. But in any case, what they seem to prioritize is to lure as much foreign investment and companies as possible to stimulate businesses and the economy. However, the possibility of a quick fix in the economy is virtually non-existent if it is to be transformational. Such approach will have inherent limitations without the expected increase in income and employment, and capital accumulation or reinvestment, if many other conditions that Africans themselves need to satisfy are not met. And these are essentially all human factors: strong oversight for business support, a business-facilitating environment, sound corporate governance, a high level of economic-mindedness and rational thinking, a sense of public duty and ownership, discipline amongst officials, etc.

Should African economies undergo structural transformation, the conventional path would be to move from a traditional economy to an industrial economy, and then to a tertiary industry economy. The world is buzzing about 'industry 4.0' or the fourth industrial revolution, which is the new generation industrial revolution that combines manufacturing technologies and ICT. ${ }^{6}$ Such a development path is that which developed countries have undergone. The UK was the leader in industrialization, and other European countries and the US followed suit. In Asia, Japan was the first to successfully transform and later South Korea realized unprecedented compressed economic growth. 
There is no economically developed country that remains a primarily agricultural economy without a manufacturing industrial capability. Even an agriculture-based economy will need a certain level of manufacturing capability in order to reap meaningful benefits from its agricultural sector. And it requires much greater industrialization to move to the second phase of development, and then to the third phase of tertiary industry or the service sector, which includes commerce, finance, insurance, tourism, public health, mass media, consulting, education, entertainment and logistics.

Unfortunately for developing countries, we are now living in the era of globalization that is so much more competitive. Such an environment inhibits the growth of domestic industries in the 'fragile' economies of Sub-Saharan Africa. Rather than moving along each stage in a linear trajectory, developing countries may have to pursue all these three phases concurrently, given the circumstances of today's globalized world. ${ }^{7}$

However, African countries should not give up industrialization because they need to, and actually can, achieve industrialization, even while the age of 'new globalization' of industrial robots and 3D printers is dawning before us: their best chance of industrializing in the coming decades will be to focus on intra-regional trade and targeting agriculture-based industrialization, because these are less affected by global competition and trends. The developing agricultural sector is also crucial in that it can absorb the fast-growing youth population into rural areas. $^{8}$

On the other hand, while Africa's industrialization lags behind, the new global developments may now work to Africa's advantage: the impact of digitization of production and the trend towards locating manufacturing closer to markets-what Baldwin termed the new globalization and the phenomenon of the 'great convergence'. 'Such characteristics of the 'new globalization' like greater participation by emerging economies and the growing role of small enterprises is I think worth noting from Africa's perspective.

According to the McKinsey Global Institute, the 'new globalization' that has emerged in the twenty-first century is different from the 'old globalization' of the twentieth century, and these two forms of 
globalization have contrasting features: tangible flows of physical goods vs. intangible flow of data and information; flows mainly between advanced economies vs. greater participation by emerging economies; capital and labour-intensive flows vs. more knowledge-intensive flows; transportation infrastructure being critical for flows vs. digital infrastructure becoming equally important; multi-national companies drive flows vs. the growing role of small enterprises and individuals; the flow mainly of monetized transactions vs. more exchanges of free contents and services; ideas diffusing slowly across boarders vs. instant global access to information; and innovation flows from advanced to emerging economies vs. innovation flows in both directions. ${ }^{10}$

Some argue that leapfrogging in terms of technology is both possible and desirable for many Sub-Saharan African nations. To a certain extent, this is already happening in the region, like the widespread usage of wireless internet and mobile phones forgoing communication requiring wire connection, and economic transactions using ICT like mobile money services. Others point out the global trend of the expanding service sector and the dwindling manufacturing sector, but this does not negate the need for Africa to continuously pursue industrialization.

\section{Reflecting on the Korean Experience and Africa's Reality}

Korea's economic dynamism is a testament to the veracity of the principles of the market economy. As we have seen, Korea did not rely solely on market mechanisms, but it certainly used markets to its full advantage. There are differing views on whether Korea's economic success is due to the adoption of orthodox capitalism and free market-oriented policies, but it is fair to say that Korea utilized other measures to supplement and reinforce capitalism and markets, and not to substitute them. In hindsight, this was perhaps inevitable and necessary. Otherwise, Korea would not have achieved such a feat if it were not for the extraordinary measures it took, considering the disadvantageous conditions and state of underdevelopment in which it found itself. 
All things considered, the Korean model of development does provide good lessons and reference points for emulation for Sub-Saharan African countries. Although the Korean case can be considered an exceptional and dramatic example, and hence difficult for others to replicate with success, this does not diminish its value and relevance-it serves as a forceful reminder of what is possible for developing nations.

One of the lessons to draw from Korea's experience is that development efforts can only work if they are supported by the essential 'foundations' that must be put in place at the early stages of development. This is to say that a sort of 'multi-tasking' is required. The reason why economic and development policies do not work well in Sub-Saharan African countries is that the basic foundations that are necessary to support them are very weak or almost non-existent.

There cannot be a quick fix to economic challenges and the fundamentals must always be observed. If development is to take place nationally and sustainably, then industrialization should go hand in hand with rural-agricultural development and empowerment of the people. The industrial sector cannot be built out of thin air. Even if the physical conditions are favourable for industrialization, there is still a need for human resources to make it work. In order for factories to properly operate, what is required are capital, a skilled labour force, good management, a steady supply of utilities, satisfactory infrastructures, etc. In the region, things tend to degenerate into vicious circles because one thing after another is lacking, and there is little effort made to fix the situation.

Returning to the fundamentals of economics, the basic production factors—land, labour and capital_are all necessary means for industrialization, and technology, which is treated as an exogenous variable in economics, is a key element for enhancing production. In order for any underdeveloped country to modernize, it would need capital in the form of both physical and human capital. So, how can countries amass the necessary capital for development in the first place? The answer is that they should start with utilizing what is already available to them. In the early stages of economic development or industrialization, except for city states or commercial hub cities, the majority of the populace would be living in rural areas, working in the primary sectors that 
include agriculture, livestock, forestry, fisheries, etc. Without the development of these sectors, there cannot be wealth creation enabling a transition to the secondary industry of reprocessing and manufacturing, ranging from light industries to heavy industries.

As we have already seen, the Korean government laid the groundwork for industrial transformation with rural reform, namely land reform and pro-poor empowerment of people policies, before embarking on an export drive in the early 1960s. The Saemaul Undong was launched in 1970, and following this, urban and rural development was concurrently pursued, while export promotion and the Saemaul Undong produced synergistic effects.

The ideal for developing countries would be to push for agriculturalrural sector development and industrialization at the same time in a way that results in these two producing mutually reinforcing effects. But in Africa, the primary industry largely remains 'traditional agriculture'. A sensible path for economic development would be prioritizing industrialization in the agricultural sector, where their comparative advantage lies. This makes sense not only economically but also politically, because the vast majority of people are villagers and farmers. Today, as the marginalization of the rural populace continues amid a population explosion and worsening income disparities, the countries should have no choice but to deal with this challenge more proactively.

The example of Korea is not the only case of vindication of the propoor rural-agricultural policy for developing countries. Unlike many African countries, Korea is resource-poor and has unfavourable natural conditions. Africa, with its vast arable land, fertile soil and abundance of natural resources, has all the more reason to be enthusiastic and focused on rural-agricultural development. Scholars who have studied the divergence in development between Asian and African countries will notice what is underlying the situation, as David Henley does:

In South-East Asia, elite attitudes to village life, although condescending, are often also marked by nostalgia and a degree of admiration. Although Africa has had no lack of rulers with rural origins, their attitude to rural life has mostly been much less positive. Consequently they have tended to see development not as a matter of improving the living conditions of the 
peasant masses in situ, but rather as a question of accelerating the transition from rural backwardness to urban modernity, of which their own lives have been a microcosm. This has led them to favour elitist development strategies aimed at acquiring symbols of developed-country status (universities, steelworks, information technology, human rights) rather than meeting the urgent practical challenge of making poor people richer by whatever means lie immediately at hand. ${ }^{11}$

It is understandable that in Africa, frustrations are vented by those who follow the news on global trends like 'the fourth industrial revolution'. A Ugandan intellect asks:

Why Sub-Saharan Africa has never undergone an industrial and manufacturing revolution, despite repeated declarations and summit communiqués by heads of state during the past 50 years? ... we must try to look for the root causes, while acknowledging that the failure to industrialise is not due to absence of blue prints or elaborate government policy documents in the ministries, like that of industry. Today, we live in an era of national visions, with target dates, to which we add international blue prints issued by the United Nations. ${ }^{12}$

He went on to admit that the role of the government is central for industrialization, but blamed the dictates of the World Bank and the IMF's liberalization for greatly undermining the role of the state.

The tasks for latecomers to industrialization were to learn, emulate and adopt the know-how and technology of advanced industrial economies. Under the circumstances, Sub-Saharan African countries need a combination of technologies: hi-tech, modern, conventional and appropriate. The benefit of being developing countries is that it is easy to get technical transfers from other countries. These and so many other things should have already been done by African countries. And let us not forget that before contemplating the 'industrial revolution' and developing the manufacturing sector, rural-agricultural development initiatives should have been undertaken.

Speaking of the capitalist economic system, there were a number of different types of capitalism in the world history. A crude form of market economy had existed since the beginning of world civilization, and 
agrarian capitalism, mercantilism and industrial capitalism existed well before modern free-market capitalism. ${ }^{13}$ What should be noted is that nearly all the currently existing capitalist economies are mixed economies, which combine elements of free markets with state intervention and, surely in some cases, economic planning. There is no such thing as a $100 \%$ liberal market economy in our reality, as pointed out by Ha-Joon Chang (2002, 2008, 2010). On 'transformative industrial policy for Africa', Chang stressed that industrialization must remain at the centre of African development, despite the prevailing economic orthodoxy, and that manufacturing and agriculture can work to support each other. He saw that African countries can still find room amid World Trade Organization regulations and the penetration of monopoly producers to achieve high levels of development through industrialization. ${ }^{14}$

No doubt, as was argued by Joseph Schumpeter, capitalism is the most effective economic system that the world has seen, as it creates wealth through the continuous process of advancing levels of productivity and technological sophistication. Therefore, in order to advance the state of economic development of African countries, due attention must be paid to advancing their 'capitalistic system' in terms of economic performance. However, amid vague expectations that somehow the free market will get things working, the fundamentals have been ignored. And what happened to innovations and 'creative destruction' that are supposed to come about following the progression of capitalism in Africa?

For decades, the Washington Consensus, the imposition of the neo-liberalist approach and even the giving of foreign aid itself were frequently cited by Africans and others as obstacles to Africa's development. But irrespective of the extent to which these have actually had an impact on African countries, these countries cannot be 'exonerated' from failing to carry out their innate responsibilities. The case of Korea is a sobering reminder of what needs to be done for a poor nation to move up the ladder of development, and its lesson is that aid, whether in the form of grants or financial loans, will be helpful when properly utilized. Foreign assistance itself is not the problem, as it is simply a means to an end. One can use it usefully or render it useless, and aid 
would not necessarily root out resources for the private sector or inhibit its growth. Business and the economy fail not flourish in the region not because there is too much aid, but because there is a lack of economic activities in the first place: modest entrepreneurship, a non-committal attitude when it comes to economic activities and investing their resources for future gains, etc.

Successful and creative entrepreneurs have certainly emerged in SubSaharan Africa, but they are too few in number and it takes much more than talented businessmen to turn around the economy. Recent reports confirm that Africa is still the most commodity-dependent continent in the world. In order to uplift and invigorate the economy, African countries need to have manufacturing industries that can export to create jobs and generate income for the rapidly growing population. Of course, it has become harder to industrialize. When developed countries and Asian countries industrialized, they did so in a different international setting from that in which African countries now find themselves. However, we should ask why Africa has not been able to build up a manufacturing industry when many others have been able to do so. As even African Development Bank experts point out, regardless of the hurdles facing Africa today, 'manufacturing remains the best hope for SSA to generate a large number of good jobs and reduce the prospects of political and social instability'. ${ }^{15}$

Achieving successful economic transformation would be unthinkable without an evolution in the manufacturing sector. Yes, there has been a lot of talk of entrepreneurship and buzz about business start-ups in many Sub-Saharan African countries, encouraged by the likes of CNN's African Start Up and Africa Marketplace programmes. While this is to be commended as positive, there is also some cause for worry. Leaving the vast segment of the populace in the private sector to survive in the wilderness of open markets by virtue of their creativity may be not the most responsible thing to do. Even in one of the most innovative countries like Korea, today about $70 \%$ of all start-up businesses fail within a few years. We should heed the warnings that premature deindustrialization is neither a desirable nor an inevitable trend for developing countries. 
Many prominent scholars like Dani Rodrik, Ha-Joon Chang and Joseph Stiglitz have stressed the importance of realizing and deepening industrialization for developing countries. As noted earlier, Rodrik has written about the 'perils of premature deindustrialization'. Chang stressed that the idea put forward by neo-liberalists that countries can skip the industrialization phase and move on to the deindustrialization stage is simply an illusion; since the service industry is inherently smallscale and has limitations in terms of its production capacity, it cannot be a sufficient driving force for economic growth. Furthermore, service goods are not easily traded, so service sector-based economies lack exporting capabilities; according to Chang, this in turn curtails export earnings and the ability to purchase foreign technologies, jeopardizing economic growth. ${ }^{16}$

Joseph Stiglitz has lately expressed that the government plays a central role in shaping the economy, not only through formal policies (industrial, and expenditure and tax), but also in writing the rules of the game, and the economic structure is inevitably affected by the way in which the government structures markets. ${ }^{17}$ In that sense, Stiglitz mentions that every country has an industrial policy, but some countries do not know it, and when governments are not self-conscious in their direction of the economy, this opens up the possibility of special interests greatly influencing the economy, leading to pervasive inefficiencies, lower growth and more inequality. ${ }^{18}$

One would think that Korea has already achieved a full cycle of industrialization, but in his recent book There Is No Korea After 3 Years, Byeong Ho Gong warns Korea against deprioritizing the manufacturing sector. ${ }^{19}$ If the manufacturing industry is still vital for countries like Korea, which is the sixth-largest exporting nation in the world, what does this say about other developing countries?

Building an industrial economy for Sub-Saharan African countries should begin in the agricultural sector. In fact, on many occasions, African heads of state have convened to be reminded of, and recommit to, this need. For instance, they recommitted themselves to the Comprehensive Africa Agriculture Development Programme (CAADP) in Malabo in 2014. The CAADP is a continental framework with a 2025 vision for promoting inclusive growth and prosperity through 
investment in the agricultural sector. African countries are said to have taken the lead and put in place their own National Agriculture Investment Plans (NAIPs). Once again, there is no lack of expression, but the problem always lies in the implementation. The commissioner for the rural economy and agriculture at the African Union Commission writes:

According to World Bank, evidence shows that in sub-Saharan Africa (SSA), investing in agriculture is 11 times more rewarding in reducing poverty than investment in other sectors. Data show that $80 \%$ of marketed agricultural production in SSA comes from smallholders, 60\% being women. The issue, therefore, is no longer whether the agriculture sector is important; it is rather how Africa should invest boldly in its agrifood systems so as to leapfrog the structural transformation of the overall African economies ... In order to sustain the achievement and to accelerate the implementation of agricultural plans, countries will need to invest in systemic capacity building. The youth should be equipped with knowledge, if we want our agriculture to go the extra mile. African countries should rethink their capacity building strategies by focusing more on vocational training. ${ }^{20}$

A collective awareness that agriculture must be the priority sector to target for Africa's development seems to have materialized and gathered momentum among African leaders and experts, as well as international organizations like the World Bank. Without any doubt, the establishment of a sound agricultural industry will form the bedrock of economic transformation in Sub-Saharan African countries.

As much as rural-agricultural development is strategic for SubSaharan Africa, its realization cannot be expected to happen overnight either. However challenging the task may be, African governments and peoples must be patient and persist in their efforts. To begin with, while it would be desirable to add value to agricultural products and enhance the value chain, it is also crucial, in the meantime, to boost the production of crops. People were inclined to believe that because there is no market and poor infrastructure to transport agricultural goods in Africa, there is no use producing in mass quantities. But more and more African 
farmers are realizing that good production, in terms of both quantity and quality, is paying off. The stable production of large amounts of commodities of consistent quality are what everybody - the government, investors, private firms, donors and international organizations-is looking for, and the demand for these seems to be on the rise.

Korea's experience underscores the importance of the agricultural sector. Korea realized its Green Revolution and White Revolution during the period of the modernization drive in 1970s and 1980s. Throughout Korea's history, for the sake of stability and security amid external threats and invasions, increasing food production was a longcherished desire of the nation. From the early 1960s, Korea set out its first National Economic Development Plan to pursue self-sufficiency in food production, making it a priority on the national agenda. As the government actively pursued various policies to increase food productivity, by the latter half of 1970 s, Korea was able to achieve $100 \%$ selfsufficiency in rice production, which is the main national staple. ${ }^{21}$ The achievement of self-sufficiency in rice production in Korea is referred to as the Green Revolution. This was accomplished through R\&D efforts in the agricultural sector and a new technology transfer system, such as increased rice productivity through improved rice varieties, as well as the development of cultivation technologies and the swift dissemination of new technologies to farmers.

This process was also driven by the government's commitment through its policies and practices on building infrastructure related to rice production, flexible production and supply chains for materials such as fertilizers and chemical pesticides. Self-sufficiency in rice production became a cornerstone for strengthening the basis of national economic development not only for procuring food security and boosting incomes of farm households, but also for saving foreign currency required to import foreign rice.

The White Revolution refers to the modernization of the structure, material and technology of greenhouses in Korea needed to achieve the rapid expansion of protected cultivation areas and to produce a stable supply of vegetables from the 1970 s to the 1990 s. The name derives from the extensive use of white-coloured plastic or polyethylene films for greenhouses. Before the 1970s, all plastic films were imported into 
Korea, but greenhouse vegetable production became popular from the 1970s onwards, when Korea built up its petrochemical industry. In this respect, industrialization greatly benefited the agricultural sector.

Before vinyl houses or greenhouses were used in Korea, vegetables could not be grown in winter, but once they became available, farmers were able to produce them all year round, which also benefited consumers, who could enjoy fresh vegetables all the time. In the 1980s, flower growing became possible, and now even fruits (including some tropical fruits) are being produced in greenhouses in Korea. Nowadays, 'smart greenhouses' with remote control technology are being developed. The White Revolution greatly contributed to Korea's rural employment and income generation, which in turn helped support the national economy. Economic growth as well as government plans and policies enabled the rapid expansion of protected cultivation using greenhouses in a very short period of time. ${ }^{22}$

Another critical element in Korea's successful development is the land reform that has been mentioned earlier. In many African countries, the system of ownership of land is managed in a 'flexible' but 'random' manner. While there is a need not to disrupt the status quo in land rights for the sake of social stability, a systematic and universal designation of land ownership must be enacted in the longer run for the efficient use of land for economic purposes.

\section{Relevance of the Korean Development Model or Experience}

South Korea's development experience and 'model' has many implications for Sub-Saharan African countries and it should be heeded from a practical as well as an academic viewpoint. Having come across a wide range of works on Africa's development conducted by a multitude of entities and having attended so many meetings, seminars and lectures on the topic, I cannot shrug off the impression that today's business in development has become too technical and routine, without being substantive. We seem to be lost in a world of logic and science, as if 
sharing rational and sophisticated thinking is the solution to problems. However, the essence of development is about doing, often needing to touch base with people at the grassroots level.

Africa's development programmes have failed to bear fruit not because the methods were wrong, but because people were not enacting them. Hence, the task is twofold: to basically 'adapt' to local conditions, but at the same time to 'challenge' the locals to change their attitudes and behaviour for the better. Thus, how to bring about change is key, and shaping perceptions, incentives and disincentives (or 'punishments') are of great importance. In this respect, Korea's development experience can provide useful food for thought as the Korean model is, in itself, an epitome of 'development as practice'.

In this respect, so much needs to be done, and one part of this is strengthening the social capital in African communities and society at large from the standpoint of practicality. However, albeit slowly, a certain level of awareness and endeavours to this end seem to be materializing in the region. For instance, Amin Mawji, who is the Representative of the Aga Khan Development Network (AKDN) in Uganda, has compiled best practice ideas of civil society in Africa in his book Poverty to Prosperity, in which he emphasizes values and ethics besides highlighting the best practices, and notes that 'an interesting challenge facing society today is how to motivate people from a cross-section of society - across tribe, colour, creed - to collaborate, to work together, to share'. ${ }^{23}$

The success of Sub-Saharan African countries is not assured even if they all adopt the same model of development, but their performance will depend not only on how they work on the basics, but also on how they compete and collaborate among themselves. And in the end, each nation has to figure out and pursue the best strategy for it to be competitive. And there is no need to prejudge or presume what is appropriate for the countries on their behalf. The value of the development model and examples should be gauged not on how much they can be easily replicated, but rather on how much motivation and positive impact they can bring to the countries.

Some experts are dismissive of the Korean case, claiming that it is an exceptional case and one which cannot have much relevance for developing countries. But there is strong merit in the Korean case being 
dramatic, forceful and clear-cut, and thus it should not be dismissed. In terms of an educated population, a skilled workforce and a sense of national unity, Korea may have been ahead of Sub-Saharan African countries at the time of its independence, but it was at a greater disadvantage in other areas. Also, many developing countries at that time surpassed Korea in various categories.

One could point out the different international setting for Korea at the time, which might have been more favourable for it compared to what African countries faced then and now. But on the flip side, it could be argued than some African countries as well as many other non-African developing countries may have had many more advantages than Korea in different ways. Generally, there are always many different ways to undertake personal, organizational, social and national tasks. If people make it a habit to think ahead and learn from previous experiences, the assignments they assume can be more easily and routinely carried out. This will enable more activity, output and speed.

People who harbour pessimistic realism or classist ideology may think that African leaders and elites, and foreign governments and companies, want the maintenance of the status quo in Africa-that is, continued underdevelopment-in order to safeguard their vested interests. And I also have heard from ordinary Africans that their leaders and ruling elites seem to not want the people to become enlightened or empowered because they fear that this might endanger their privileged status and interests. Some even suggest that African leaders are now themselves practising colonialism by exploiting their own people.

Resorting to tribalism, ethnic-regional division, taking advantage or fomenting security threats and conflicts, abusing security-military apparatus, etc. are traditional methods of ruling and maintaining power in many parts of the developing world, especially Africa. And unfortunately, in most instances, electoral democracy has degenerated into unwholesome contests to maintain power, influence and wealth. But the reality holds many truths. Normally, political leaders would neither be totally exploitive nor benign, but would fall somewhere in between these extremes. And no African leader would be able to fully manipulate and suppress their people. By all indications, the current rulers of Sub-Saharan 
African countries are nowhere near the position of wielding complete control over their people without also jeopardizing their own status.

African leaders, from their perspective, could be apprehensive of the rise of public disgruntlement towards them, which can lead to social unrest. Internet usage and social media have also become widespread in Africa, and regional and international pressures are also significant, so that African rulers also have to watch their backs. All in all, Africa's persistent problems are primarily due not to the monolithic power of governments suppressing their people, but to a lack of coherence and unity in the nation, and a weak sense of purpose and commitment for development among leaders and people in general. The crux of the matter is that the nature of Africa's problems is portrayed mostly in terms of people's 'rights' (through the political prism), when in fact it is really about 'work ethics' or social conduct (functional, economic attributes). Today, just about everything is seen in a political light, and Africa's development is perhaps the greatest victim of this.

When the priority of African countries should be placed on finding human solutions to what are obviously problems of human nature, whether superficial or deep-seated, the trend of our times is moving away from this, following business, technical and educational sophistication, and the fanfare of innovation. So, there can be a misplaced 'conviction that progress can only be achieved by a quantum leap from (rural) backwardness to (urban) modernity'. ${ }^{24}$ And what is also concerning is that the gap between the 'two worlds' inside African countries seems to be widening instead of narrowing.

Pursuing the trend of the times is a natural and smart thing to do. But such efforts will be hollow if the more fundamental tasks facing a nation are skipped over or forgotten altogether. South Korea was able to transform itself into a developed economy in such a short time not because it merely exerted itself in terms of adopting to the trend of the times, but, more importantly, because it focused vigorously in closing the 'development gap' by means of expeditiously tackling the innate basic obstacles that are characteristic of poor countries.

Who can refute that a nation has to be diligent for it to be successful in all aspects of life? This is self-evident, but I can hardly see any utterance of the word 'diligence' or 'hard work' in today's world, as if 
this is a thing of the past. Now and then, I see African leaders scolding their officials for being negligent and failing to get the job done, but I have rarely heard them enunciating the value of diligence as a norm that the civil servants or people should practise. Korea's turnaround required extraordinary work on the part of the people. If the Korean people were not supportive of the government's policies and did not actively take part in the development process, the nation would not have achieved such progress.

Many people seem to misunderstand that development or transformation will somehow occur over time and can be prompted by 'transfers' of capitals, know-how, technology, etc. But development is not about 'knowing', 'getting' or just desiring; rather, it is essentially about 'doing' things. Unfortunately for African countries, the world is becoming increasingly competitive and the human capital gaps are widening. This is why a dramatic turnaround in the mindset of the African population is necessary sooner rather than later. This is because development or transformation is equivalent to 'change', and the scale and depth of positive change over time matters. 'Speed' is also critical because if the changes take too long, it will offset any gains and might lead to other problems and even to regression. When you are nimble, there are advantages because you not only can go faster, but you can also have more time to fix things or turn back to find other routes when things are not right. A good example of this is Korea's response to the 1997 IMF bailout crisis.

Another crucial factor is the role of the government. South Korea is just one of many cases throughout history attesting to the importance of active government intervention to induce economic transformation and growth. We do not need to go back hundreds of years to the likes of Frederick List, Benjamin Franklin and Alexander Hamilton to be reminded of the genesis and tradition of government intervention to support the industry and economy. Today, governments of the developed world play expansive roles, albeit in a more intricate and technical fashion than in the past.

I have yet to see a businessman who has not admitted that the government's assistance is vital for his business. This holds true for all businessmen, regardless of their nationality and location. When it comes to 
doing business overseas, especially in new markets and in unfamiliar territories like Africa, businessmen say that the government's intervention is all the more crucial. Many advanced countries, including the US, are very regulatory in nature. The consequences of the 2008 global financial crisis give the case in point, proving the necessity of this stance. As for developing countries, governments can and should promote economic growth by playing an active role of facilitator and taking vigorous pro-capitalistic measures. Most importantly, the states should focus their energies on pushing for industrialization alongside the development of the rural-agricultural sector.

This is where the logic of 'economic discrimination' comes in. The word 'competition' is of essence in the economic world. And the forces that promote positive competition are incentives and disincentives or 'punishments'. If governments can be instrumental in encouraging many winners to emerge, this will spur economic growth. The economic history of the world is about winners. The rise and fall of powers, the surge of Western economies and the new rivalry unfolding among major economic powers today can all be seen in the context of who emerges triumphant over others. Hence, the future of the economies of Sub-Saharan African countries will hinge on whether and to what extent they espouse the rule of competitive economy and society.

There is an opportunity for change in the midst of challenges in SubSaharan Africa. The dissatisfaction of the masses in relation to their livelihood and the performance of states can remain latent and subdued, or can accumulate to generate pressure for reform, or cause unrest and chaos. But the leaders cannot remain complacent and idle because in order to stay in power, they have to be able to mobilize the resources to meet the minimum public demands. Most of all, the population explosion and the growing unemployed youth phenomenon must be dealt with before it reaches an untenable level.

What African leaders and governments have been doing is not working, nor is it desirable in terms of development. There are clear limitations on what foreign entities like foreign businesses, development partners, international organizations and NGOs can do for African countries, and whatever measures they take, it will revert to how African nations respond and what actions they take. 
Therefore, the solution lies in breaking the psychological yoke- that they do not have the capability and are destined for underdevelopment - that has inhibited Africa from moving forward with confidence. As Ha-Joon Chang (2010) pointed out, Africa is not destined for underdevelopment: Africans are not poor because of any mysterious or immutable factors; they are poor for the same reasons other nations were once poor, which means that their poverty can be fixed if they apply the same solutions that other nations have applied. But before the right policies can be pursued, the psychological barrier that is at the heart of Africa's problem must be overcome.

\section{Notes}

1. IMF, Regional Economic Outlook-Sub-Saharan Africa Restarting the Growth Engine (April, 2017), p. 3. For 2016, most oil-exporting nations were in recession (with a contraction in GDP growth), while conditions in many other resource-rich countries also faced difficulties: continued political uncertainty (South Africa), weak fundamentals (Ghana) and acute droughts (Lesotho, Malawi, Zambia, Zimbabwe).

2. Jakkie Cilliers, 'Made in Africa-Manufacturing and the Fourth Industrial Revolution', Africa in the World Report 8, Institute for Security Studies, April 2018, pp. 7, 11.

3. A. Gelb, C. Meyer, V. Ramachandran, and D. Wadhwa, 'Can Africa Be a Manufacturing Destination? Labour Costs in Comparative Perspective', Centre for Global Development, Working Paper 466, 15 October 2017. Jakkie Cilliers, 'Made in Africa-Manufacturing and the Fourth Industrial Revolution', Africa in the World Report 8, Institute for Security Studies, April 2018, p. 11.

4. Ramathan Goobi, discussing 'IMF Regional Economic Outlook for Sub-Saharan Africa', presentation by Clara Mira, Country Representative of the IMF for Uganda, at ESAMI, Kampala, 15 June 2017.

5. 'How the Taxman Slows the Spread of Technology in Africa', The Economist, Middle East and Africa, 9 November 2017.

6. The first Industrial Revolution used water and steam power to mechanize production; the second used electric power to create 
mass production; the third used electronics and information technology to automate production; the fourth is building on the third, the digital revolution that has been occurring since the middle of the last century. It is characterized by a fusion of technologies that is blurring the lines between the physical, digital and biological spheres. See http://www.weforum.org/agenda/2016/01/ the-fourth-industrial-revolution-what-it-means-and-how-to-respond.

7. Continued globalization and technological progress (the fourth Industrial Revolution), an increasingly competitive international market amid the rise of emerging economies, among other factors, make the prospects of Sub-Saharan Africa's industrialization and structural transformation uncertain. The age of linear economic/industrial transformation may not be easy or sensible to pursue. In certain cases and areas, 'leap-frogging' might be both practical and inevitable because, for instance, ICT technology has already pervaded widely in the societies and economies of Sub-Saharan Africa.

8. Rafiq Raji, 'Additive Manufacturing: Implications for African Economies', How We Made It in Africa, 25 October 2017, https:// www.howwemadeitinafrica.com/additive-manufacturing-implicationsafrican-economies/60103.

9. Baldwin, The Great Convergence: Information Technology and the New Globalization (Cambridge, MA: Harvard University Press, 2016).

10. McKinsey Global Institute, 'Digital Globalization: The New Era of Global Flows', March 2016, https://www.mckinsey.com/business-functions/digital-mckinsey/our-nsights/digital-globalization-the-new-eraof-global-flows.

11. David Henley, Asia-Pacific Development Divergence-A Question of Intent (London: Zed Books, 2015), p. 25.

12. Semakula Kiwanuka, 'Why Has Sub-Saharan Africa Never Undergone Industrial Revolution?', New Vision (Ugandan daily), 24 March 2016.

13. See Ellen Meiksins Wood, 'The Agrarian Origins of Capitalism', Monthly Review 50, no. 3 (July-August 1998); Robert A. Degen, The Triumph of Capitalism (New Brunswick: Transaction Publishers, 2011), p. 12.

14. Ha Joon Chang, 'Transformative Industrial Policy for Africa: Put Manufacturing at the Centre of Development', speech given at the Second Annual Adebayo Adedeji Lecture, 3 April 2016, Addis Abbaba, provided by UNECA.

15. Haroon Bhorat, Ravi Kanbr, Christopher Rooney, and Francois Steenkamp, 'Sub-Saharan Africa's Manufacturing Sector: Building 
Complexity', Working Paper Series No. 256, May 2017. African Development Bank, pp. 9-10.

16. Ha Joon Chang, 23 Things They Don't Tell You About Capitalism (London: Penguin Books, 2010). The points made regarding markets and role of government are: (1) 'There is no such thing as a free market'; (7) 'Free-market policies rarely make poor countries rich'; (12) 'Governments can pick winners'; (16) 'We are not smart enough to leave things to the market'; (21) 'Big government makes people more open to change'; (23) 'Good economic policy does not require good economists.'

17. Joseph Stiglitz, Rewriting the Rules of the American Economy: An Agenda for Growth and Shared Prosperity (New York: W.W. Norton, 2015).

18. Joseph Stiglitz, 'Industrial Policy, Learning and Development', in John Page and Finn Tarp (eds), The Practice of Industrial Policy: GovernmentBusiness Coordination in Africa and East Asia (Oxford: Oxford University Press, 2015), pp. 23-39; WIDER Working Paper 2015/149, published by UNU-WIDER and the Korean International Cooperation Agency, Helsinki, Finland, December 2015.

19. Byeong Ho Gong, There Is No Korea After 3 Years (Seoul: Ishipilsegibooks, 2016) (Korean).

20. 'Why Strong Leadership Is Necessary to Transform African Agriculture', article written by Rhoda Peace Tumusiime, the Commissioner for Rural Economy and Agriculture of African Union (AU) Commission, appeared in New Vision (Uganda), 28 March 2016, p. 16.

21. Sok-Dong Kim et al., The Green Revolution in Korea-Development and Dissemination of Tongil-Type Rice Varieties (Seoul: KDI, 2012).

22. Rural Development Administration (http://www.rda.go.kr/foreign/ ten). See also Hyo-duk Seo et al., White Revolution of Agriculture in Korea: The Achievement of Year-Round Production and Distribution of Horticultural Crops by the Expansion of Greenhouse Cultivation (Sejong: RDA, 2013) (Korean), pp. 15-18.

23. Amin Mawji, Poverty to Prosperity: Empowering the Future, Best Practice Ideas from Civil Society (Kampala: Graphic Systems Uganda Limited, 2017).

24. David Henley and Ahmad Helm Fuady, 'Sources of Developmental Ambition in Southeast Asia and Sub-Saharan Africa', Developmental Regimes in Africa-a joint initiative between Africa Power and Politics (APPP) and Tracking Development-Policy Brief no. 4, January 2014, p. 3. 
Open Access This chapter is licensed under the terms of the Creative Commons Attribution 4.0 International License (http://creativecommons. org/licenses/by/4.0/), which permits use, sharing, adaptation, distribution and reproduction in any medium or format, as long as you give appropriate credit to the original author(s) and the source, provide a link to the Creative Commons license and indicate if changes were made.

The images or other third party material in this chapter are included in the chapter's Creative Commons license, unless indicated otherwise in a credit line to the material. If material is not included in the chapter's Creative Commons license and your intended use is not permitted by statutory regulation or exceeds the permitted use, you will need to obtain permission directly from the copyright holder. 